\title{
Reactive Granulomatous Dermatitis during Anti-TNF Therapy: A Case Report and Review of the Literature
}

\author{
Cassone $G^{1 *}$, Citriniti $G^{1}$, Sebastiani $M^{1}$, Manfredi $A^{1}$, Cesinaro $A M^{2}$ and Ferri $C^{1}$ \\ ${ }^{1}$ Rheumatology Unit, Azienda Ospedaliero-Universitaria Policlinico di Modena, University of Modena and Reggio Emilia, Italy \\ ${ }^{2}$ Department of Anatomic Pathology, Azienda Ospedaliero-Universitaria Policlinico di Moden, Italy
}

*Corresponding author: Giulia Cassone, Rheumatology Unit, Azienda Ospedaliero-Universitaria Policlinico di Modena, University of Modena and Reggio Emilia, Via del Pozzo, 71, 41100 Modena, Italy, Tel: +39-059-4225295, E-mail: cassonegiu@libero.it

\begin{abstract}
Tumor Necrosis Factor (TNF)- $\alpha$ blockers have been shown to be highly effective in the treatment of arthritis not responsive to traditional therapy. In parallel, there are an increasing number of reports about the development of cutaneous side effects after the administration of anti-TNF- $\alpha$ agents. Noninfectious cutaneous granulomatous reactions include granuloma annulare, non-caseating granuloma, sarcoid-like granulomatosis and also a wide spectrum of conditions recently unified under the term of reactive granulomatous dermatitis.

The majority of the above reported granulomatous dermatitis is associated with an underlying inflammatory disorder, and almost all may be drug-induced. Moreover, a substantial overlap, both in clinical and histologic features, is present between these conditions.

We describe a reactive granulomatous dermatitis in a patient with psoriatic arthritis treated with adalimumab, resolved after the TNF- $\alpha$ inhibitor discontinuation, and we summarize the recent case-reports in which reactive granulomatous dermatitis were observed in patients with arthritis receiving various TNF- $\alpha$ inhibitors. Reactive granulomatous dermatitis may be a possible long-term side effect of this class of drugs. Although TNF- $\alpha$ blockers are usually used in the treatment of granulomatous disorders, patients treated with these kinds of drugs should be carefully monitored as, in rare cases, TNF- $\alpha$ inhibitors may induce sufficient cytokine activation to support granuloma formation.
\end{abstract}

\section{Keywords}

Anti-Tnf, Adalimumab, Reactive granulomatous dermatitis, Interstitial granulomatous dermatitis, Palisaded neutrophilic and granulomatous dermatitis, Interstitial granulomatous drug reaction

\section{Introduction}

Tumor Necrosis Factor (TNF)- $\alpha$ blockers have been shown to be highly effective and they are currently used in the treatment of patients with chronic arthritis not responsive to traditional therapy $[1,2]$.

Drug induced skin lesions represent the most frequent side effect of anti-TNF $\alpha$ agents, presumably in susceptible individuals [3-10]. They include infusion/ injection site reactions, psoriasis and psoriasis-like lesions, lupus-like syndromes, vasculitis, cutaneous infections, eczematous reactions, lichenoid reactions, cutaneous lymphomas, skin cancers and granulomatous diseases [5-10]. Many noninfectious cutaneous granulomatous reactions have been described in literature, such as granuloma annulare, cutaneous sarcoidosis and sarcoid-like granulomatosis $[11,12]$. Recently, the new term of Reactive Granulomatous Dermatitis (RGD) has been proposed to unifying a wide spectrum of conditions, namely Interstitial Granulomatous Dermatitis (IGD), Palisaded Neutrophilic and Granulomatous Dermatitis (PNGD), Interstitial Granulomatous Drug Reaction (IGDR) [12]. However, the correlation between these granulomatous diseases and the use of TNF- $\alpha$ blockers is still controversial.

Here, we describe a patient with psoriatic arthritis who developed a RGD subsequently to the treatment with adalimumab, resolved after the TNF- $\alpha$ inhibitor discontinuation. 


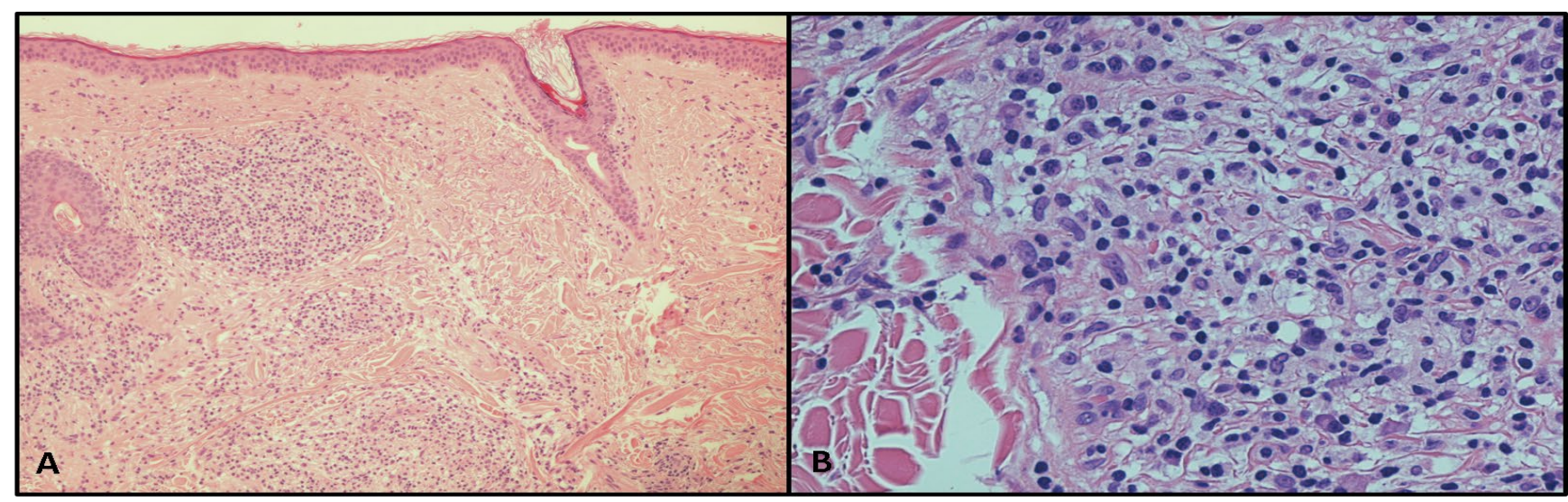

Figure 1: Routinely Hematoxylin and Eosin stained sections of the reactive granulomatous skin lesion, showing a dense perivascular and periadnexal inflammatory infiltrate $(A)$, made of histiocytes (CD68+), lymphocytes $T(C D 3+)$ and $B(C D 20+)$, some plasma cells and few isolated medium sized elements CD30+ (B).

\section{Case Description}

A 56-year-old caucasian man, with a 10-year history of psoriatic arthritis, presented to our Rheumatology Unit with a 2-months history of an itchy and erythematous skin lesion of the face with edema and infiltrated skin, associated to constitutional signs and symptoms (fever, fatigue, weight loss).

His past clinical history revealed the presence of polycythemia vera since 1999, monoclonal gammopathy of undetermined significance since November 2014 and a past gastric ulcer. He was on therapy with proton pump inhibitors and antiplatelet.

In 2005 a diagnosis of psoriatic arthritis was made, based on the evidence of psoriasis, arthritis of small joints of the hands, associated with characteristic bone erosions at feet, ankles, hands and wrists. He was treated with methotrexate, leflunomide and etanercept, all discontinued because of inefficacy or side effects. In 2010, treatment with Methotrexate (MTX) and infliximab was started, but the latter was withdrawn after one year because of a leishmaniasis infection, completely resolved after treatment with liposomal amphotericin B.

In June 2013, due to persistent disease activity, treatment with adalimumab $40 \mathrm{mg}$ every other week was started, associated to MTX $15 \mathrm{mg}$ weekly.

However, in February 2015, skin erythematous patches of 20-30 mm of diameter and plaques of the cheek appeared. The eruption extended with infiltrated nodules on nose and forehead. Together with the development of the erythema, the patient experimented malaise, gastrointestinal disorders for four days and fever up to $38^{\circ} \mathrm{C}$ for only one day.

No changes in patient's inflammatory joint disease were observed. No alteration in the complete blood count, acute phase reactants, thyroid stimulating hormone was found. Laboratory screening excluded occult infections by HCV, HBV, HIV and Treponema Pallidum; the QuantiFERON TB Gold assay and a chest X-ray were all negative and the angiotensin-converting enzyme was within normal limits.

Dermatologic evaluation considered a differential diagnosis between Sweet Syndrome, Granulomatous Rosacea and drug eruption. He was treated with tapering course of methylprednisolone and ciprofloxacine, and then with doxycycline and topical medicaments containing zinc oxide and metronidazole, without any clinical improvement. Therefore, a $6 \mathrm{~mm}$ punch biopsy was performed to aid in the diagnosis. Routinely Hematoxylin-and-eosin-stained sections showed the presence of a dense perivascular and periadnexal lymphohistiocytic infiltrate, focally granulomatous, with histiocytes (CD68+), lymphocytes T (CD3+) and B (CD20+), some plasma cells and few isolated elements $\mathrm{CD} 30+$, consistent with a reactive immune response (Figure 1). Special stains for infectious agents were negative. Fungal, bacterial, mycobacterial and parasites cultures from skin specimens were negative. A diagnosis of RGD was performed.

Because of a possible relationship between skin lesion and adalimumab treatment, anti-TNF $\alpha$ drug was stopped and a 4 months therapy with hydroxychloroquine $400 \mathrm{mg}$ /daily was started, with complete clinical remission observed in the next 5 months.

\section{Discussion}

Granulomatous dermatitis comprises a heterogeneous spectrum ranging from granuloma annulare, IGD, PNGD, IGDR, non-caseating granuloma to sarcoid-like granulomas [11-13].

The majority of the above reported granulomatous dermatitis is associated with an underlying inflammatory disorder, and almost all may be drug-induced. Moreover, a substantial overlap, both in clinical and histologic features, is present between these conditions, and their nomenclature is considered confusing by some Authors [12].

Recently, the new term of RGD has been proposed, 
Table 1: Reactive granulomatous dermatitis during anti-TNF therapy: literature review.

\begin{tabular}{|c|c|c|c|c|c|c|c|c|c|}
\hline $\begin{array}{l}\text { Authors, } \\
\text { year [Ref] }\end{array}$ & $\begin{array}{l}\text { F/M } \\
\text { (age) }\end{array}$ & Diagnosis & $\begin{array}{l}\text { TNFa } \\
\text { agent }\end{array}$ & $\begin{array}{l}\text { Concurrent } \\
\text { treatment }\end{array}$ & $\begin{array}{l}\text { Duration } \\
\text { of use }\end{array}$ & $\begin{array}{l}\text { Type of } \\
\text { gronulomatous } \\
\text { lesions }\end{array}$ & Location & $\begin{array}{l}\text { Discontinuation } \\
\text { of TNFa }\end{array}$ & $\begin{array}{l}\text { Treatment } \\
\text { and Outcome }\end{array}$ \\
\hline $\begin{array}{l}\text { Present } \\
\text { case, } 2016\end{array}$ & M (56) & PA & ADA & MTX & $20 \mathrm{~m}$ & $\begin{array}{l}\text { Skin } \\
\text { erythematous } \\
\text { patches of } 20-30 \\
\text { mm of diameter } \\
\text { and plaques, } \\
\text { infiltrated } \\
\text { nodules }\end{array}$ & $\begin{array}{l}\text { Cheek, } \\
\text { nose, } \\
\text { forehead }\end{array}$ & Withdrawal & $\begin{array}{l}\text { CS and } \\
\text { ciprofloxacin, } \\
\text { doxycycline, } \\
\text { metronidazole } \\
\text { - no } \\
\text { improvement; } \\
\text { HCQ - } \\
\text { resolved }\end{array}$ \\
\hline \multicolumn{10}{|c|}{ Palisaded Neutrophilic and Granulomatous Dermatitis (PNGD) } \\
\hline \multicolumn{10}{|c|}{ Bremner, et al. [25] } \\
\hline$\# 1$ & $F(57)$ & $\mathrm{RA}$ & IFX & MTX & $3 \mathrm{~m}$ & $\begin{array}{l}\text { Annular papules } \\
\text { and plaques }\end{array}$ & $\begin{array}{l}\text { Medial } \\
\text { thighs, } \\
\text { axillary } \\
\text { folds, back }\end{array}$ & $\mathrm{nr}$ & $\begin{array}{l}\text { DPS - } \\
\text { improved }\end{array}$ \\
\hline \#2 & $F(27)$ & RA & IFX & MTX & $\mathrm{nr}$ & $\begin{array}{l}\text { Papules/ } \\
\text { Vescicles and } \\
\text { papules }\end{array}$ & $\begin{array}{l}\text { Buttocks, } \\
\text { posterior } \\
\text { thighs/ } \\
\text { palms, } \\
\text { fingers }\end{array}$ & $\mathrm{nr}$ & $\begin{array}{l}\text { CS DPS } \\
\text { HCQ - modest } \\
\text { improvement }\end{array}$ \\
\hline \#3 & $F(54)$ & RA & ETA & $\mathrm{nr}$ & $\mathrm{nr}$ & Nodules & $\begin{array}{l}\text { Legs and } \\
\text { feet }\end{array}$ & $\begin{array}{l}\text { ETN replaced } \\
\text { with INF }\end{array}$ & $\begin{array}{l}\text { Topical TCR } \\
\text { - modest } \\
\text { improvement }\end{array}$ \\
\hline \multicolumn{10}{|c|}{ Deng, et al. [16] } \\
\hline$\# 1$ & $F(48)$ & RA & IFX & & $\mathrm{nr}$ & $\begin{array}{l}\text { Generalized } \\
\text { annular nodules } \\
\text { and plaques }\end{array}$ & $\begin{array}{l}\text { Back and } \\
\text { shoulders }\end{array}$ & Withdrawal & $\begin{array}{l}\text { Improved, lost } \\
\text { follow-up }\end{array}$ \\
\hline \#2 & $F(65)$ & RA & IFX & & $\mathrm{nr}$ & $\begin{array}{l}\text { Macules and } \\
\text { plaques }\end{array}$ & $\begin{array}{l}\text { Flank and } \\
\text { forearm }\end{array}$ & Withdrawal & Resolved \\
\hline \#3 & $F(34)$ & RA & ETA & MTX & $\mathrm{nr}$ & Papules & Elbows & Withdrawal & $\begin{array}{l}\text { Lesions } \\
\text { persistence }\end{array}$ \\
\hline $\begin{array}{l}\text { Collaris EJ, } \\
\text { et al. [22] }\end{array}$ & M (57) & RA & IFX & - & $9 \mathrm{~m}$ & PNGD plaques & $\begin{array}{l}\text { Nose/ } \\
\text { extensor } \\
\text { elbow }\end{array}$ & No & $\begin{array}{l}\text { Topical } \\
\text { metronidazole } \\
\text { resolved/ } \\
\text { topical CS } \\
\text { resolved }\end{array}$ \\
\hline $\begin{array}{l}\text { Stephenson } \\
\text { SR, et al. } \\
{[13]}\end{array}$ & $F(56)$ & RA & ADA & MTX, CS & $24 \mathrm{~m}$ & $\begin{array}{l}\text { PNGD patches } \\
\text { and plaques }\end{array}$ & Legs & Withdrawal & $\begin{array}{l}\text { AZA, CS - } \\
\text { cleared }\end{array}$ \\
\hline $\begin{array}{l}\text { Umezawa } \\
\text { Y, et al. [26] }\end{array}$ & $F(64)$ & RA & ADA & CS & $10 \mathrm{~m}$ & $\begin{array}{l}\text { PNGD papules } \\
\text { erythema, } \\
\text { purpura }\end{array}$ & $\begin{array}{l}\text { Hands, } \\
\text { plantae }\end{array}$ & Withdrawal & $\begin{array}{l}\text { Topical CS } \\
\text { - cleared } \\
\text { after ADA } \\
\text { discontinuation }\end{array}$ \\
\hline $\begin{array}{l}\text { de } \\
\text { Unamuno } \\
\text { Bustos B, } \\
\text { et al. [27] }\end{array}$ & $F(41)$ & AS/RA & $\begin{array}{l}\text { ETA/ } \\
\text { ADA }\end{array}$ & - & $18 \mathrm{~m} / 8 \mathrm{~m}$ & $\begin{array}{l}\text { PNGD } \\
\text { erythematous } \\
\text { papules }\end{array}$ & $\begin{array}{l}\text { Forearms } \\
\text { and } \\
\text { elbows/ } \\
\text { fingers }\end{array}$ & Withdrawal & $\begin{array}{l}\text { Topical CS } \\
\text { resolved/ } \\
\text { persistence in } \\
\text { TCZ }\end{array}$ \\
\hline \multicolumn{10}{|c|}{ Interstitial Granulomatous Dermatitis (IGD) } \\
\hline $\begin{array}{l}\text { Patsatsi, et } \\
\text { al. [28] }\end{array}$ & $F(70)$ & RA & ADA & - & $\begin{array}{l}1 \mathrm{~m} \text { after } \\
\text { withdrawal }\end{array}$ & IGD papules & Umbilicus & $\begin{array}{l}\text { Withdrawal and } \\
\text { re-initiation }\end{array}$ & $\begin{array}{l}\text { Non response } \\
\text { to topical CS, } \\
\text { resumed ADA }\end{array}$ \\
\hline $\begin{array}{l}\text { Guerin, et } \\
\text { al. [29] }\end{array}$ & $F(61)$ & RA & ADA & & $7 \mathrm{~m}$ & IGD plaques & $\begin{array}{l}\text { Lower } \\
\text { extremities }\end{array}$ & Withdrawal & $\begin{array}{l}\text { CS, LFM - } \\
\text { resolved }\end{array}$ \\
\hline \multicolumn{10}{|c|}{ Interstitial Granulomatous Drug Reaction (IGDR) } \\
\hline $\begin{array}{l}\text { Martorell, et } \\
\text { al. [30] }\end{array}$ & $F(45)$ & PA & ADA & & $6 \mathrm{~m}$ & Nodules & Legs & Withdrawal & Cleared \\
\hline
\end{tabular}

Legend: F: Female; M: Male; RA: Rheumatoid Arthtritis; AS: Axial Spondyloarthritis; PA: Psoriatic Arthritis; PNGD: Palisaded Neutrophilic and Granulomatous Dermatitis; IGD: Interstitial Granulomatous Dermatitis; IFX: Infliximab; ADA: Adalimumab; ETA: Etanercept; MTX: Methotrexate; CS: Corticosteroids; nr: not recorded; DPS: Dapsone; HCQ: Hydroxychloroquine; TCR: Tacrolimus; AZA: Azathioprine; TCZ: Tocilizumab; LFM: Leflunomide.

to unifying three dermatologic confounding entities:

PNGD, IGD and IGDR [12].
Probably, the first cases of PNGD were described in 1965 by Dykman, et al. [14] as an "unusual form of rheu- 
matoid granuloma" in two patients with rheumatoid arthritis. Magro, et al. [15] first described IGDR in 1998 as interstitial histiocytic infiltrates with variable degeneration of collagen and elastic fibres. The implicated drugs included calcium channel blockers, angiotensin converting enzyme inhibitors, beta-blockers, lipid-lowering agents, antihistamines, anticonvulsants and antidepressants. In 2006 Deng, et al. described the first such reaction to the TNF $\alpha$ inhibitor adalimumab, and in 2010 Martorell-Calatayud, et al. described another similar case [16,17].

Table 1 summarizes the recent case-reports in which RGD (IGD, PNGD, IGDR) were observed in patients with arthritis, receiving various TNF- $\alpha$ inhibitors (Table 1).

In the present case-report we describe a RGD, one of the possible inflammatory patterns of cutaneous drug reaction. Histologic features of RGD may be quite frequently seen associated to a skin drug reaction, but they are not specific for any granulomatous skin lesions. Moreover, they are poorly described in literature regarding the use of anti-TNF $\alpha$ agents.

TNF $\alpha$ blockers have been also associated with the induction of autoimmune disease-like manifestations, including vasculitis, lupus erythematosus and interstitial lung disease. Twenty-eight adalimumab cutaneous immune reactions have been described, including rheumatoid nodules, non-caseating granulomas of the bone marrow, granuloma annulare [13,18-22], leukocytoclastic vasculitis, necrotizing vasculitis, cutaneous sarcoidosis, discoid lupus erythematosus, psoriasis, dermatitis herpetiformis and alopecia areata [23]. On the other hand, primary autoimmune diseases can show the same skin lesions as part of their clinical picture [11-12,24].

In our patient, the disappearance of the skin manifestations after adalimumab discontinuation is consistent with other case reports of cutaneous granulomatous dermatitis involving TNF $\alpha$ inhibitors [11,16,17,22,25-29]. Moreover, a causality assessment of the adverse drug reactions was demonstrated to be probable by using Naranjo adverse drug reaction probability scale, with a total score of 6 (meaning a probable adverse drug reaction) [30].

Despite some discordances, granulomatous reactions have been actually reported after treatment with adalimumab, infliximab and etanercept. Tong and coworkers [31] reported a higher risk of new granulomatous manifestations for etanercept than anti-TNF $\alpha$ monoclonal antibodies. In this regard, while infliximab and adalimumab increase lysis of CD4 and CD8 cells, hence reducing Interferon-expression, etanercept increases production of Interferon- $\alpha$, which is essential in granuloma formation [32]. On the contrary, other Authors underline that tuberculous granulomas are more frequent in patients treated with anti-TNF $\alpha$ monoclonal antibodies, but it can be observed also with etanercept [33]; so, other mechanisms could be implicated.

Moreover, patients with known granulomatous dis- ease have been successfully treated with TNF $\alpha$ blockers, including adalimumab [34-37].

In our patient, the differential diagnosis of granulomatous skin lesions was challenging because of his medical history. The possible developing of cutaneous sarcoidosis or a leishmaniasis exacerbation were also considered, however the histopathology revealed the presence of small granulomas with many lymphocytes, not consistent with sarcoidosis, and the presence of Leishmania amastigotes was ruled out, even using Giemsa stains.

MTX was associated to anti-TNF therapy, and its contributory role towards granuloma development could be considered. Although rare, granuloma formation can be seen, for example, in MTX-induced lung injury [38]. However, in our case MTX was continued after the adalimumab discontinuation in order to treat the joint involvement and, anyway, apparently without interfere with the disappearing of the skin lesion. This supports the causal link between anti-TNF $\alpha$ therapy and granulomatosis.

Finally, even if the clinical course of RGD appears in some cases to be self-limited, the use of hydroxychloroquine might have had a role in the healing of the skin lesion [25]. Improvement of these cutaneous diseases has been reported with topical corticosteroids, low-dose prednisone, and immunosuppressants, although it is unclear whether such treatments caused or merely coincided with resolution of the eruption, as in our patient [25].

In conclusion, atypical granuloma formation may be a possible long-term side effect of TNF $\alpha$ inhibitors, either due to an immunological mechanism or to an unknown infectious agent. In immunocompromised patients, the possible implication of infectious agents should be ever considered. Moreover, atypical drug reactions are frequently observed in patients with immune-mediated diseases [39].

Although TNF- $\alpha$ blockers are usually used in the treatment of granulomatous disorders, patients treated with this kind of drugs should be carefully monitored as, in rare cases, TNF $\alpha$ inhibitors may induce sufficient cytokine activation to support granuloma formation.

\section{References}

1. Smolen JS, Landewé R, Breedveld FC, Buch M, Burmester $\mathrm{G}$, et al. (2014) EULAR recommendations for the management of rheumatoid arthritis with synthetic and biological disease-modifying antirheumatic drugs: 2013 update. Ann Rheum Dis 73: 492-509.

2. Gossec L, Smolen JS, Gaujoux-Viala C, Ash Z, Marzo-Ortega $H$, et al. (2012) European League Against Rheumatism. European League Against Rheumatism recommendations for the management of psoriatic arthritis with pharmacological therapies. Ann Rheum Dis 71: 4-12.

3. Ramos-Casals M, Brito-Zeron P, Muñoz S, Soria N, Galiana D, et al. (2007) Autoimmune Diseases Induced by TNF-Targeted Therapies Analysis of 233 Cases. Medicine (Baltimore) 86: 242-251.

4. Ramos-Casals $M$, Roberto-Perez-Alvarez, Diaz-Lagares $C$, Cuadrado MJ, Khamashta MA, et al. (2010) Autoimmune 
diseases induced by biological agents: a double-edged sword? Autoimmun Rev 9: 188-193.

5. Moustou AE, Matekovits A, Dessinioti C, Antoniou C, Sfikakis PP, et al. (2009) Cutaneous side effects of antietumor necrosis factor biologic therapy: A clinical review. J Am Acad Dermatol 61: 486-504.

6. Flendrie $M$, Vissers $\mathrm{WH}$, Creemers MC, de Jong EM, van de Kerkhof PC, et al. (2005) Dermatological conditions during TNF-alpha-blocking therapy in patients with rheumatoid arthritis: a prospective study. Arthritis Res Ther 7: 666-676.

7. Thielen AM, Kuenzli S, Saurat JH (2005) Cutaneous adverse events of biological therapy for psoriasis: review of the literature. Dermatology 211: 209-217.

8. Devos SA, Van Den Bossche N, De Vos M, Naeyaert JM (2003) Adverse skin reactions to anti-TNF-alpha monoclonal antibody therapy. Dermatology 206: 388-390.

9. Mocci G, Marzo M, Papa A, Armuzzi A, Guidi L (2013) Dermatological adverse reactions during anti-TNF treatments: Focus on inflammatory bowel disease. J Crohns Colitis 7: 769-779.

10. Moran GW, Lim AW, Bailey JL, Dubeau MF, Leung Y, et al. (2013) Review article: dermatological complications of immunosuppressive and anti-TNF therapy in inflammatory bowel disease. Aliment Pharmacol Ther 38: 1002-1024.

11. Goldminz AM, Gottlieb AB (2013) Noninfectious granulomatous dermatitides: a review of 8 disorders (Part 1 of 3 ). Semin Cutan Med Surg 32: 177-182.

12. Rosenbach M, English JC 3rd (2015) Reactive Granulomatous Dermatitis: A Review of Palisaded Neutrophilic and Granulomatous Dermatitis, Interstitial Granulomatous Dermatitis, Interstitial Granulomatous Drug Reaction, and a Proposed Reclassification. Dermatol Clin 33: 373-387.

13. Stephenson SR, Campbell SM, Drew GS, Magro CM (2011) Palisaded neutrophilic and granulomatous dermatitis presenting in a patient with rheumatoid arthritis on adalimumab. J Cutan Pathol 38: 644-648.

14. Dykman CJ, Galens GJ, Good AE (1965) Linear subcutaneous bands in rheumatoid arthritis: an unusual form of rheumatoid granuloma. Ann Intern Med 63: 134-140.

15. Magro CM, Crowson AN, Schapiro BL (1998) The interstitial granulomatous drug reaction: a distinctive clinical and pathological entity. J Cutan Pathol 25: 72-78.

16. Deng A, Harvey V, Sina B, Strobel D, Badros A, et al (2006) Interstitial granulomatous dermatitis associated with the use of tumor necrosis factor alpha inhibitors. Arch Dermatol 142: 198-202.

17. Martorell-Calatayud A, Balmer N, Cardenas Cardona LF, Teague $D(2010)$ Interstitial granulomatous drug reaction to adalimumab. Am J Dermatopathol 32: 408-409.

18. Vavricka SR, Wettstein T, Speich R, Gaspert A, Bachli EB (2003) Pulmonary granulomas after tumour necrosis factor alpha antagonist therapy. Thorax 58: 278-279.

19. Metyas SK, Tadros RM, Arkfeld DG (2009) Adalimumab-induced non caseating granuloma in the bone marrow of a patient being treated for rheumatoid arthritis. Rheumatol Int 29: 437.

20. Voulgari PV, Markatseli TE, Exarchou SA, Zioga A, Drosos AA (2008) Granuloma annulare induced by anti-tumour necrosis factor therapy. Ann Rheum Dis 67: 567-570.

21. Scrivo R, Spadaro A, lagnocco A, Valesini G (2007) Appearance of rheumatoid nodules following anti-tumor necrosis factor alpha treatment with adalimumab for rheumatoid arthritis. Clin Exp Rheumatol 25: 117.
22. Collaris EJ, van Marion AM, Frank J, Poblete-Gutiérrez $P$ (2007) Cutaneous granulomas in rheumatoid arthritis. Int J Dermatol 46: 33-35.

23. Lee HH, Song IH, Friedrich M, Gauliard A, Detert J, et al. (2007) Cutaneous side-effects in patients with rheumatic factor-alpha antagonists. Br J Dermatol 156: 486-491.

24. Hau E, Vignon Pennamen MD, Battistella M, Saussine A, Bergis M, et al. (2014) Neutrophilic skin lesions in autoimmune connective tissue diseases: nine cases and literature review. Medicine (Baltimore) 93: e346.

25. Bremner R, Simpson E, White CR, Morrison L, Deodhar A (2004) Palisaded neutrophilic and granulomatous dermatitis: an unusual cutaneous manifestation of immune-mediated disorders. Semin Arthritis Rheum 34: 610-616.

26. Umezawa Y, Ito K, Nakagawa H (2013) Palisaded neutrophilic and granulomatous dermatitis in a rheumatoid arthritis patient after treatment with adalimumab. Eur $\mathrm{J}$ Dermatol 23: $910-911$

27. de Unamuno Bustos $B$, Rabasco AG, Sánchez RB, de Miquel VA (2013) Palisaded neutrophilic and granulomatous dermatitis associated with ankylosing spondylitis. Am J Dermatopathol 35: 847-850.

28. Patsatsi A, Kyriakou A, Triantafyllidou E, Sotiriadis D (2011) Interstitial granulomatous dermatitis: another clinical variant. Case Rep Dermatol 3: 195-200.

29. Guerin M, Haettich B, Bara C, Artru L, Prophette B, et al. (2012) Lupus attributable to anti-TNF therapy and revealed by interstitial granulomatous dermatitis. Rheumatology International 32: 2937-2940.

30. Naranjo CA, Busto U, Sellers EM, Sandor P, Ruiz I, et al. (1981) A method for estimating the probability of adverse drug reactions. Clin Pharmacol Ther 30: 239-245.

31. Tong D, Manolios N, Howe G, Spencer D (2012) New onset sarcoid-like granulomatosis developing during anti-TNF therapy: an under-recognised complication. Intern Med $\mathrm{J}$ 42: 89-94.

32. Wallis RS, Ehlers S (2005) Tumor necrosis factor and granuloma biology: explaining the differential infection risk of etanercept and infliximab. Semin Arthritis Rheum 34: 34-38.

33. Furst DE, Wallis R, Broder M, Beenhouwer DO (2006) Tumor necrosis factor antagonists: different kinetics and/or mechanisms of action may explain differences in the risk for developing granulomatous infection. Semin Arthritis Rheum 36: 159-167.

34. Min MS, Lebwohl M (2016) Treatment of recalcitrant granuloma annulare (GA) with adalimumab: A single-center, observational study. J Am Acad Dermatol 74: 127-133.

35. Mahmood T, Mansouri B, Menter A (2015) Successful treatment of generalized granuloma annulare with adalimumab. Clinical and Exprimental Dermatology 40: 537-539.

36. Lukács J, Schliemann S, Elsner P (2015) Treatment of generalized granuloma annulare - a systematic review. J Eur Acad Dermatol Venereol 29: 1467-1480.

37. Burns AM, Green PJ, Pasternak S (2012) Etanercept-induced cutaneous and pulmonary sarcoid-like granulomas resolving with adalimumab. J Cutan Pathol 39: 289-293.

38. Lateef O, Shakoor N, Balk RA (2005) Methotrexate pulmonary toxicity. Expert Opin Drug Saf 4: 723-730.

39. Prinz JC (2011) Autoimmune-like syndromes during TNF blockade: does infection have a role? Nat Rev Rheumatol 7: 429-434. 